УДК 338.12

\title{
УПРАВЛІННЯ КОНКУРЕНТОСПРОМОЖНІСТЮ ПІДПРИЄМСТВА
}

\author{
Геращенко I.O., к.е.н., доцент, \\ Шмадченко О.О. студентка (УІПА)
}

\begin{abstract}
В статті систематизовано поняття конкурентоспроможності підприємства, розглянуто багатогранність трактувань вчених економістів, наведено систему показників для оцінки становища конкурентоспроможності підприсмства, розглянуто основні рівні конкурентоспроможності підприємства, охарактеризовано методи оиінки конкурентоспроможності та розроблено модель для оцінки становища підприємства $i$ прийняття відповідного рімення в управлінні
\end{abstract} конкурентоспроможністю підприємства. конкурент.

Ключеві слова: управління, конкуренція, конкурентоспроможність підприємства, розвиток,

\section{УПРАВЛЕНИЕ КОНКУРЕНТОСПОСОБНОСТЬЮ ПРЕДПРИЯТИЯ}

Геращенко И.А., к.э.н., доцент, Шмадченко А.А. студентка (УИПА)

В статье систематизировано понятие конкурентоспособности предприятия, рассмотрено многогранность трактовок ученых экономистов, приведена система показателей для оценки положения конкурентоспособности предприятия, рассмотрень основные уровни конкурентоспособности предприятия, охарактеризованы методы оценки конкурентоспособности и разработана модель для оченки положения предприятия и принятия соответствующего решения в управлении конкурентоспособностью предприятия. конкурент.

Ключевые слова: управление, конкуренция, конкурентоспособность предприятия, развитие,

\section{MANAGEMENT COMPETITIVENESS OF ENTERPRISE}

\author{
Herashchenko I.O., c.e.s., associate professor, \\ Shmadchenko O.O. student (UIPA)
}

In the paper the concept of enterprise competitiveness, scientists examined the diversity of interpretations of economists, the definition from our point of view, the notion of competitiveness, considered a system of indicators to assess the situation of the competitiveness of enterprises, the basic level of competitiveness of enterprises describing the behavior of enterprises in each of the levels characteristic of methods for assessing competitiveness.

The model of competitiveness management company, determined the factors which influence the company projected level of enterprise competitiveness by changing the actions of these factors, the ways are systematized and it means to increase the competitiveness of developing a set of measures to improve the competitiveness and further appropriate action in enterprise management .

Keywords: management, competition, competitiveness, development, competitor.

Постановка проблеми. Світ не стоїть на місті, весь час змінюються умови конкурентної боротьби, виникає глобалізація ринку, інтеграція господарюючих суб'єктів, розвиваються технології, удосконалюються методи управління. На сучасному етапі економічного розвитку конкуренція, як рушійна сила, змушує виробників постійно шукати нові шляхи підвищення своєї конкурентоспроможності. Практично перед усіма підприємствами постали проблеми виживання, що вимагають негайного вирішення. Існує досить велика кількість методів та підходів щодо оцінки рівня конкурентоспроможності. Однак не має єдиного підходу який дозволяє проводити оцінку послідовно та застосовувати для підприємств різного виду діяльності.

Аналіз останніх досліджень і публікацій. Питанню оцінки конкурентоспроможності приділяли багато уваги у вітчизняній і зарубіжній науці такі вчені, як: Азоєв Г. [1], Белоусов В.Л. [2], Балабанова Л. [3], Воронкова А. Е. [4], Дикань В.Л.[4] Должанський I.3.[6] Шевельова С [7], 
Піддубна Л. [8], Піддубний І. [9], Фатхутдінов Р. [10], Книш М. І. [11], Портер М.Э. [12], Клименко C.M. [13], Завьялов П., Шинкаренко В. Г, Ліфіц I.M., Гончаров В., Сахненко I. В, [14]. Хейс Р, Уілрайт С., Кларк Д. [15] та ін.

Мета цієі статті полягає в систематизації сутності конкурентоспроможності підприємства, аналізі основних рівнів конкурентоспроможності підприємства, характеристиці основних методів оцінки та розробці моделі управління конкурентоспроможністю підприємства.

Розгляд основного матеріалу. Одним iз головних показників який виражає сутність ринкових відносин є конкурентоспроможність та конкуренція на ринку між підприємствами. Так як підприємство $\epsilon$ головною ланкою ринкової економіки, то високий рівень конкурентоспроможності підприємства дозволяє сформувати конкурентну економіку регіону, галузі та країни в цілому[5].

Конкуренція - це рушійна сила, яка дозволяє розвивати підприємства та максимально задовольняти потреби споживачів, покращуючи товари та послуги. Термін «конкуренція» 3 лат. concurrentia означає - змагання, суперництво.

Слід звернути увагу на багатозначність трактувань сутності поняття «конкурентоспроможність» сучасними вченимиекономістами ( табл.1). Конкурентоспроможність підприємств необхідно розглядати 3 урахуванням ієрархічності цього поняття, зважаючи на існування причинно-наслідкових зв'язків та супідрядності конкурентоспроможності на усіх рівнях управління економікою (держава, підприємство, продукція) [16].

Таблиия 1

Погляди вчених-економістів на категорію «конкурентоспроможність»

\begin{tabular}{|c|l|}
\hline Автор & \multicolumn{1}{|c|}{ Визначення конкурентоспроможності } \\
\hline Книш М.І [10] & $\begin{array}{l}\text { Ступінь привабливості даного продукту, для здійснення реальної покупки } \\
\text { споживачем. }\end{array}$ \\
\hline Ожегов С.І.[13] & Здатність витримувати конкурента, протистояти конкурентам. \\
\hline Забєлін П.В., & $\begin{array}{l}\text { Здатність приносити прибуток у короткостроковому періоді не нижче } \\
\text { заданого, або перевищення над середнім прибутком. }\end{array}$ \\
\hline Грошев В.П.[14] & $\begin{array}{l}\text { Комплекс споживчих властивостей товару, що визначає його відмінність від } \\
\text { інших аналогічних товарів по ступеню й рівню задоволення потреб покупців } \\
\text { і витратам на його купівлю й експлуатацію. }\end{array}$ \\
\hline Портер М. Е. [12] & $\begin{array}{l}\text { Властивість суб'єкта ринкових відносин виступати на ринку нарівні } \\
\text { присутніми там конкуруючими суб'єктами ринкових відносин }\end{array}$ \\
\hline Стівенсон В. [14] & $\begin{array}{l}\text { Характеристика того, «наскільки ефективно компанія задовольняє потреби } \\
\text { клієнта порівняно з іншими компаніями, що пропонують подібний товар або } \\
\text { послугу». }\end{array}$ \\
\hline Дикань В.Л. [5] & $\begin{array}{l}\text { Здатність підприємства здійснювати свою діяльність в умовах ринкових } \\
\text { відносин і одержувати при цьому прибуток, достатній для науково-технічного } \\
\text { удосконалення виробництва, стимулювання працівників і підтримки } \\
\text { продукції на високому якісному рівні. }\end{array}$ \\
\hline $\begin{array}{l}\text { Хруцький В.С., } \\
\text { Корнєєва І.В. [18] }\end{array}$ & $\begin{array}{l}\text { Стабільна можливість задовольняти певні потреби покупців краще, ніж } \\
\text { фінансовими результатами для виробника. }\end{array}$ \\
\hline Фатхутдінов Р.А.[10] & $\begin{array}{l}\text { Властивість об'єкта, що характеризується ступенем реального чи } \\
\text { потенційного задоволення ним конкретної потреби у порівнянні } \\
\text { аналогічними об'єктами, представленими на даному ринку. }\end{array}$ \\
\hline
\end{tabular}

Загалом можна сказати, що конкурентоспроможність - це відносна характеристика, яка відображає тенденції розвитку певного підприємства-виробника від виробниківконкурентів, як за ступенем задоволення власними товарами, так й за ефективністю виробничої діяльності.

Конкурентоспроможність

характеризується системою показників, які дають смогу оцінити становище підприємства, а саме: конкурентоспроможність продукції, технології, потенційних можливостей обладнання, рівня персоналу, системи управління, рівня інновацій, стану комунікацій, рівня маркетингової політики, експортно-імпортних можливостей та інших параметрів.

В світовій практиці згідно Р. Хейс, С. Уїлрайт і Д. Кларк [14], виділяють основні рівні конкурентоспроможності підприємства, які дозволяють розподілити підприємства за цими рівнями i оцінити конкурентоспроможність конкретного підприємства по відношенню до підприємств - конкурентів відповідного рівня (табл.2). 
Основні рівні конкурентоспроможності

\begin{tabular}{|c|c|}
\hline Рівень & \multicolumn{1}{|c|}{ Поведінка підприємств } \\
\hline Перший & $\begin{array}{l}\text { Керівництво свою роль бачить лише в тому, щоб випускати продукцію, не піклуючись } \\
\text { ні про які сюрпризи для конкурентів і споживачів; }\end{array}$ \\
\hline Другий & $\begin{array}{l}\text { Компанії прагнуть до того, щоб їх підприємства повністю відповідали стандартам, } \\
\text { які встановлені їх основними конкурентами; }\end{array}$ \\
\hline Третій & $\begin{array}{l}\text { Компанії досягають успіху в конкурентній боротьбі, завдяки функції управління, якості, } \\
\text { ефективності управління і організації виробництва в найширшому сенсі; }\end{array}$ \\
\hline Четвертий & $\begin{array}{l}\text { Компанії кидають виклик будь-якому конкуренту по всьому світу в будь-якому } \\
\text { аспекті виробництва або управління; це підприємства світового класу }\end{array}$ \\
\hline
\end{tabular}

Конкурентоспроможність підприємства не $€$ постійною характеристикою, вона визначає здатність вести успішну конкурентну боротьбу, протистояти у певний період основним конкурентам. Зі змінами у зовнішньому та внутрішньому середовищах змінюються також порівняльні конкуренті переваги щодо інших підприємств галузі [19].

Конкурентоспроможність підприємства залежить від об'єкта порівняння, а також від факторів, які застосовуються для оцінки конкурентоспроможності [6]. Також на основі існуючих показників конкурентоспроможність залежить і метод оцінки конкурентоспроможності підприємства.

Класифікація методів оцінки конкурентоспроможності підприємства передбачає їх поділ на окремі групи за певною ознакою. Найчастіше такою

ознакою виступає форма представлення результатів оцінки.

Методи оцінки конкурентоспроможності підприємства наведено в таблиці 3.

Таблиця 3

Методи оцінювання конкурентоспроможності підприємства

\begin{tabular}{|c|c|}
\hline Метод & Характеристика \\
\hline Метод переваг & $\begin{array}{l}\text { Оцінка конкурентоспроможності підприємства являє собою порівняння його } \\
\text { характеристик, властивостей чи марок товарів, що порівнюються } 3 \text { аналогічними } \\
\text { показниками пріоритетних конкурентів (такими, які займають найкращі позиції на } \\
\text { даному ринку) } 3 \text { метою визначення показників, які створюють переваги } \\
\text { підприємства над конкурентами в будь-якій галузі діяльності. }\end{array}$ \\
\hline "Метод профілів" & $\begin{array}{l}\text { За його допомогою виявляють різні критерії задоволення потреб споживачів } \\
\text { щодо будь-якого продукту, а також вимірюють техніко-економічні характеристики } \\
\text { досліджуваного продукту і порівнюють їх } 3 \text { характеристиками продуктів- } \\
\text { конкурентів. Також використовують багатокутники як окремих товарів так і фірм, } \\
\text { галузей. }\end{array}$ \\
\hline Матричний & $\begin{array}{l}\text { Базуються на використанні матриці - таблиці впорядкованих по рядках та } \\
\text { стовпцях елементів. Найбільш показовим прикладом може слугувати системи } \\
\text { координат: по вертикалі - темпи росту місткості ринку, що розміщуються по рядках } \\
\text { матриці у лінійному масштабі; по горизонталі, тобто по стовпцях матриці - в } \\
\text { логарифмічному масштабі відкладається відносна частка виробника продукції на } \\
\text { ринку. }\end{array}$ \\
\hline $\begin{array}{c}\text { Метод } \\
\text { інтегральної оцінки }\end{array}$ & $\begin{array}{l}\text { Інтегральний показник рівня конкурентоспроможності підприємства містить } \\
\text { два елементи: критерій, що показує ступінь задоволення потреб споживача, і } \\
\text { критерій ефективності виробництва. }\end{array}$ \\
\hline $\begin{array}{l}\text { Метод бальної } \\
\text { оцінки }\end{array}$ & $\begin{array}{l}\text { Полягає у складанні відповідних таблиць, оцінці показників та їх порівняння } \\
\text { із підприємствами-конкурентами. }\end{array}$ \\
\hline
\end{tabular}

Головним завданням будь-якого підприємства $є$ завоювання кращої конкурентної позиції на ринку за рахунок формування, підтримки та розвитку конкурентної переваги, i, як наслідок, одержання більших економічних вигід, тому стратегічною метою управління конкурентоспроможністю формування, підтримка та розвиток стратегічної конкурентної переваги [20].

Пропонуємо модель, яка на нашу думку дасть змогу оцінити стан підприємства та допоможе в прийнятті найефективніших рішень при управлінні конкурентоспроможністю підприємства (рис 1.) 


\begin{tabular}{l}
\hline Вияв чинників зовнішнього та внутрішнього середовища \\
\hline Групування чинників, аналіз їх міжгрупових взаємозв'язків \\
\hline Оцінка впливу чинників на рівень конкурентоспроможності підприємства \\
\hline Прогнозування змін згідно виявлених чинників \\
\hline Прогнозування рівня конкурентоспроможності підприємства \\
\hline Систематизація шляхів та методів підвищення конкурентоспроможності \\
\hline Розробка комплексу заходів щодо підвищення конкурентоспроможності \\
\hline Оцінка витрат на реалізацію розроблених заходів \\
\hline Вибір критерію ефективності заходів по підвищенню \\
\hline $1 \perp L$ \\
\hline Визначення ефективності розроблених заходів та вибір оптимального \\
\hline Прийняття відповідних управлінських рішень \\
\hline
\end{tabular}

Рис.1. Модель управління конкурентоспроможністю підприємства

Для прийняття рішень управління конкурентоспроможністю підприємства, необхідно пройти декілька етапів, спочатку виявити чинники, які мають вплив на підприємство, згрупувати чинники для подальшої їх оцінки, щоб з'ясування як саме вони впливають. Спрогнозувати рівень конкурентоспроможності після зміни впливу чинників та виходячи 3 цього за допомогою методів розробити заходів щодо підвищення конкурентоспроможності, розрахувати витрати на реалізацію цих заходів та вибрати критерії, завдяки яким буде зрозуміло чи $\epsilon$ дієвою відповідна методика. На останніх етапах необхідно оцінити чи $є$ ефективними розроблені заходи та прийняти рішення щодо реалізації чи зміни комплексу заходів для підвищення рівня конкурентоспроможності відповідного підприємства.

Висновки данного дослідження. В данному дослідження було розглянуто сутність управління конкурентоспособністю підприємства, було виявлено багатогранність поняття кункурентоспроможність та представленно в вигляді таблиці погляди вчених-економістів на категорію «конкурентоспроможність». 3 нашої точки зору було визначено, що конкурентоспроможність - це відносна характеристика, яка відображає позитивий розвиток певного виробника, в порівнянні с виробником конкурентом, як по ступеню задоволення власними товарами, так й по ефективності виробничої діяльності. Було виявлено що, конкурентоспроможність можна оцінювати шляхом порівняння конкурентних позицій кількох підприємств на певному ринку, i представлено обов'язкові оціночні параметри порівняння.

основні $\begin{gathered}\text { Також було охарактеризовано чотири } \\ \text { рівні }\end{gathered}$ підприємства. Визначено, що конкурентоспроможність визначають показники різного роду, а конкретний набір залежить від методу оцінки, було охарактеризовано методи оцінки, такі як: метод переваг, структурний та функціональний, "метод профілів", матричний, інтегральної оцінки та бальна оцінка. Також, представлено модель, яка на нашу думку дасть змогу оцінити стан підприємства та допоможе в прийнятті найефективніших рішень при управлінні конкурентоспроможністю підприємства. В подальших дослідженнях необхідно провести систематизацію та розробити критерії оцінки конкурентоспроможності підприємства. 


\section{СПИСОК ЛІТЕРАТУРИ}

1. Азоев Г.Л. Конкурентные преимущества 2000. - 284 с.

фирмы / Г.Л. Азоев, А.П. Челенков/ М.:Тип.Новости, 2000.-256с.

2. Белоусов

В.Л. конкурентоспособности фирмы / В.Л Белоусов // пер. с англ. - М.: Альпина Бизнес Букс, 2005. - С. 37 Маркетинг в России и за рубежом №5. - 2001

13. Клименко

3. Балабанова Л.В., Холод В.В. Стратегічне конкурентоспроможністю маркетингове управління конкурентоспроможністю Навчальний посібник. /[ Клименко С.М. Дуброва підприємства. Н Навчальний посібник. - .: ВД О.С., Барабась Д.О. та ін.] - К.: КНЕУ, 2006. - 527 с. «Професіонал», 2006

14. Райзберг Б. А. Современный

4. Воронкова А.Е. Діагностика стану экономический словарь / Б. А., Райзберг Л. Ш. підприємства: теорія і практика: [Текст] монографія Лозовский, Е.Стародубцева Б.. 5-е изд., перераб. и / А.Е. Воронкова [та ін.]. - Харків: ІНЖЕК, 2006. - доп. - М.: ИНФРА-М, 2007. — 495 с. — (Б-ка $448 \mathrm{c}$

5. Дикань В.Л. Стратегічне управління: словарей "ИНФРА-М").

15. Хейс, Р. Стратегический менеджмент: навчальний посібник / В.Л. Дикань, В.О. Зубенко, учебник [Текст] / Р. Хейс, С. Уилрайт, Д. Кларк; пер. І.В. Токмакова, О.В. Маковоз, О.В. Шраменко. - К.: с англ. Н.И. Алмазовой. - М.: ООО «Издательство «Центр учбової літератури», 2013. - 272 с.

6. Должанський Проспект», 2003. - 32 с.

I.3. 16. Тарнавська Н.П. Управління Конкурентоспроможність підприємства: Навч. конкурентоспроможністю підприємств: теорія, посібник. / І.З. Должанський, Т.О Загорна.- К.: методологія, практика / Н.П. Тарнавська . Центр навчальної літератури, 2006. - 384 с. $\quad$ Тернопіль: Економічна думка, 2008. - 570 с.

7. Шевельова С.О. Конкурентоспроможність 17. Забелин П.В. Основы стратегического молочного п підкомплексу

[С.О. управления. / П.В.Забелин//-М.: ИнформационноШевельова].Монографія-Тернопіль:Збруч,2001.- $\quad$ внедренческий центр «Маркетинг», 2008. - 195 с.

$408 \mathrm{c}$.

18. Хруцький В.С. Сучасний маркетинг /

8. Піддубна Л. І. Конкурентоспроможність Хруцький В.Є., Корнєєва І.В., АвтуховаЕ.Э. - М.: економічних систем: теорія, механізм регулювання «Фінанси і статистика»,2004.- $461 \mathrm{c}$.

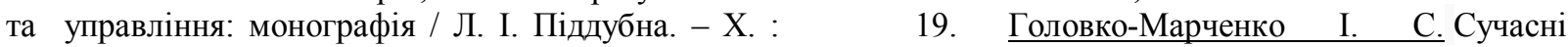
ІНЖЕК, 2007. $-368 \mathrm{c.}$

9. Піддубний підходи до розуміння сутності поняття Теорія "конкурентоспроможність підприємства" / I. C. сучасний стан і Головко-Марченко // Вісник економіки транспорту і предметно-методологічні аспекти розвитку / I. промисловості. - 2013. - Вип. 43. - С. 67-73

Піддубний, Л. Піддубна // Економіка України. - 20.2 Прохорова В. В. Управління 2007. - № 8. - C. 52-60.

10. Фатхутдинов Р.А. Управление на засадах контролінгу: монографія / В. конкурентоспособностью организации: Учебное В.Прохорова, В. І. Чобіток; МОНМС України, Укр. пособие. / Р.А. Фатхутдинов- М.: Изд-во Эксмо, інж.-пед. акад. - Х. : НТМТ, 2012. - 247 с. - Бібліогр.: 2004. $-544 \mathrm{c}$.

c. $231-247$

Рецензент д.е.н., професор УІПА Прохорова В.В. Експерт редакційної колегії к.е.н., дочент УкрДУЗТ Боровик Ю.Т.

\title{
УДК 657.471
}

\section{ВИЗНАЧЕННЯ ЕФЕКТИВНОСТІ СИСТЕМИ УПРАВЛІННЯ ВИТРАТАМИ}

\author{
Лисьонкова Н.М., к.е.н., доцент, \\ Буряковська І.О., студентка (УкрДУЗТ)
}

Розглядаються зміст і відмінність понять «ресурси», «витрати». Встановлено взаємозв'язок процесів використання ресурсів підприємства і управління витратами, визначено функиіональні елементи управління витратами. Викладена концепџія адаптивно-функиіонального підходу, який 